\title{
Redefining the role of metal production during the Bronze Age of south-eastern Iberia. The mines of eastern Sierra Morena
}

\author{
Luis Arboledas-Martínez, Eva Alarcón-García \\ Department of Prehistory and Archaeology, University of Granada, Granada, ES \\ arboledas@ugr.es; eva@ugr.es
}

\begin{abstract}
Researchers have traditionally paid little attention to mining by Bronze Age communities in the south-east of the Iberian Peninsula. This has changed recently due to the identification of new mineral exploitations from this period during archaeo-mining surveys carried out in the Rumblar and Jándula valleys in the Sierra Morena Mountains between 2009-2014, as well as the excavation of the José Martín Palacios mine (Baños de la Encina, Jaén). The analysis of the archaeological evidence and the archaeometric results reveal the importance of mining and metallurgical activities undertaken by the communities that inhabited the region between 2200 and 900 cal BC, when it became one of the most important copper and silver production centres during the Late Prehistory of south-eastern Iberia.
\end{abstract}

KEY WORDS - Bronze Age; south of the Iberian Peninsula; prehistoric mining; copper; silver; archaeomining surveys; excavation; lead isotope analysis

\section{Preoblikovanje vloge pridobivanja kovin v bronasti dobi na območju jugovzhodnega Iberskega polotoka. Rudniki vzhodne Sierre Morene}

IZVLEČEK - Raziskovalci so v preteklosti posvečali le malo pozornosti rudarstvu bronastodobnih skupnosti v jugovzhodnem delu Iberskega polotoka. Do spremembe je prišlo nedavno s prepoznavanjem novih sledov izkoriščanja mineralov iz tega obdobja, in sicer med arheo-rudarskimi terenskimi pregledi $v$ dolinah reke Rumblar in Jándula $v$ gorah Sierre Morene v letih 2009-2014, kot tudi $z$ izkopavanji rudnika José Martín Palacios (Baños de la Encina, Jaén). Analiza arheoloških podatkov in arheometričnih rezultatov je pokazala pomembnost rudarskih in metalurških aktivnosti skupnosti, ki so živele v tej regiji med 2200 in 900 pr.n.št., ko je le-ta postala eden najbolj pomembnih središč za pridobivanje bakra in srebra na jugovzhodnem Iberskem polotoku v času pozne prazgodovine.

KLJUČNE BESEDE - bronasta doba; južni Iberski polotok; prazgodovinsko rudarstvo; baker; srebro; arheo-rudarski pregledi; izkopavanja; analiza stabilnih izotopov svinca

\section{Introduction}

Metallurgy has traditionally been considered a key aspect in the study of Early Bronze Age societies (2200-1550 cal BC) in south-eastern Iberia, otherwise known as the Argaric Culture. The Argaric communities were the result of a long process of growing inequality that began in the Copper Age and led to deep-seated social inequalities and individualized identities (Lull 1983; Chapman 2008). During the Argaric period, major changes came about in the do- mestic and funerary spheres, as well as in the settlement pattern with respect to the previous period. Settlements of circular huts became sites built with artificial terraces and rectangular dwellings. Most villages were established on steep hills, although some are attested on the plains. Burials were individual and inside dwellings. Artefacts also changed typologically, including the standardized shapes of copper, silver and gold ornaments, and weapons 
such as swords and halberds (Lull 1983; Chapman 2008; Aranda et al. 2015).

These changes are also observed in agricultural practices, where an intensification of production occurred in the southeast of the Iberian Peninsula. There is an increase in the cultivation of species such as hull-less barley (Hordeum vulgare L.) and naked wheat (Triticum aestivum/durum), together with various legumes or plants such as flax (Buxó 1997; Montes 2014). At the same time, pollen studies carried out in some settlements have shown a retreat of forested areas as a result of land being brought into cultivation (Rodríguez-Ariza 2011). This intensification has been related to the spread of extensive monoculture dryland cereal farming in coexistence with garden areas (Araus et al. 1997), although other authors have proposed a more extended use of irrigation (Mora-González et al. 2018).

During this stage, the production of metal objects also intensified, with an almost five-fold increase over the Copper Age (Montero 1993; Murillo et al. 2015). There were important technological innovations, such as bronze and tin alloys, the development of silver metallurgy, goldwork and improved control over the techniques of forging and annealing objects (Montero 1991; Rovira, Gómez 2003). We also observe a change in the typology of metal objects. Ornamental objects (bracelets, pendants, earrings, rings and diadems) reflect new design concepts for personal adornment. Such items comprise more than half of all Argaric metal objects (Murillo, Montero 2012). Finally, some tools made of metal (copper and bronze), such as knives, awls and axes, began to gain in importance and to replace those from the preceding period made of bone and stone (Lull et al. 2010).

Research into the Argaric culture dates back to the late nineteenth century (Siret, Siret 1887), which has made it the most thoroughly researched Bronze Age culture in Iberia (Aranda et al. 2015). Since the 1970s, various scholars have claimed that craft specialisation in metallurgy was a crucial factor in the appearance of social inequalities (Lull 1983; Lull et al. 2010). Other researchers attribute a secondary value to metallurgy, stating that it did not require full-time specialisation. Its expansion would have been the result, not the cause, of a developing social hierarchy. That cause was more likely to be found in changes that came about in the organization of subsistence production (Gilman 1987; Montero, Murillo 2010).
The fact that there are no traces of prehistoric mining to be found in the south-east of the Iberian Peninsula has been used as a key argument for both hypotheses. In the first one, the lack of prehistoric exploitations is explained by the purportedly scarce use of these mines, as they would have been rendered unnecessary by the existence of the large metal production centre in the Sierra Morena region, which would have supplied the whole south-east (Lull et al. 2010). In the second line of research, the lack of evidence is explained by the abundance of mineral resources, mainly copper and silver, throughout the south-east, and the scarce production would have left little evidence of extractive activities, with those there were being almost unrecognizable today (Montero, Murillo 2010.41).

In this whole debate, a fundamental aspect of the process of copper- and silver-based metal production has been overlooked: mining itself. Research focusing on metallurgical mining production on the Iberian Peninsula is rather scarce, apart from a few exceptions (Blanco, Rothenberg 1981; Hunt-Ortiz 2003; Blas-Cortina et al. 2013). Until the 1980s, we had only sporadic, general information on southeastern Iberia. The exceptions include the mining engineers in the late nineteenth and early twentieth centuries, such as Pedro Mesa y Álvarez (1890), who pointed out the possible existence of prehistoric mining, although they did not offer any archaeological data. Claude Domergue (1987) was the first to analyse prehistoric mines with archaeological evidence. In his catalogue of ancient mines and foundries of the Iberian Peninsula, he mentions 11 mining sites distributed throughout the south-east with remains of ophite and diorite hammers, which he dates to the Late Prehistoric Period.

This situation has started to change recently thanks to the research that the La Bastida team is carrying out in Murcia, and the Peñalosa team in the eastern Sierra Morena Mountains (Jaén). The fieldwork of the La Bastida project in the coast mountain ranges of Murcia have allowed the discovery of two new mining areas with macrolithic objects: one in Filón Consuelo (Cartagena) and the other in Mina Balsitas (Mazarrón) (Escanilla, Delgado 2015). In the Cerro Minado mine (Huercal-Overa, Almería), archaeological evidence (stone tools) was also found, and ${ }^{14} \mathrm{C}$ dated its use to the Copper Age (Delgado et al. 2014).

Since 2001, within the Peñalosa project, we have been studying prehistoric mining in the south of the Iberian Peninsula, more specifically in the eastern 
Sierra Morena Mountains (Contreras et al. 2004; Arboledas, Contreras 2010; Arboledas et al. 2015; 2017). One of the main objectives was to find and analyse the copper and silver mines that existed in the region. The fieldwork and lab-work have provided us with important data and information, which are analysed in this article. The new data proves the existence of a major copper production centre in this area during the Bronze Age. The analysis of the archaeological remains and the analytical data have enabled us to propose new hypotheses and to highlight the need to revisit already existing hypotheses about the organization of metal production and its role in the development of the second millennium BC communities in the south-eastern Iberian Peninsula.

\section{The prehistoric mines in the eastern Sierra Mo- rena Mountains}

This research focuses on the mining area known as Linares-La Carolina, which is located in the eastern part of the Sierra Morena Mountains, to the north of the province of Jaén. Geologically, this area is part of the southern part of the Iberian Central Plateau, which features predominantly Paleozoic material (schist, slate and quartzite) and plutonic rocks, and which is cut through by a network of fractures and veins (IGME 1977.3-4).
Mineralization appears in veins and seams rich in lead-silver and copper minerals, most of which are contained in granites in the areas of contact between plutonic and sedimentary rocks, and in quartzite and slate of the Ordovician. This fact determined the methods and techniques used to exploit these mineralized deposits throughout history, with a predominance of trenches (trench) and small galleries rather than open pits or galleries and rooms-and-pillars, as happens in the southwest of the Iberian Peninsula.

The seams present mineralization of lead $(\mathrm{Pb})$, leadsilver ( $\mathrm{Pb}-\mathrm{Ag})$, copper-lead $(\mathrm{Cu}-\mathrm{Pb})$ and copper-iron $(\mathrm{Cu}-\mathrm{Fe})$, as well as some tin-tungsten (Sn-W). The mineralization in this region presents a great variety. Thus, there are areas where the seams are rich in lead sulfides, mainly argentiferous galena, with important silver grades, such as El Centenillo, and others with important copper mineralization, such as the Jándula valley, the middle valley of the Rumblar and Linares (Azcarate 1972). All the prehistoric mines documented archaeologically until now in the eastern Sierra Morena Mountains were dug in the copper seams of those areas that are embedded in granites of the Pedroches batholith of the province of Jaén.

During the first stages of mining in this region, only the copper mineralizations, both native and simple

\begin{tabular}{|c|c|c|c|c|}
\hline No. & Site & Evidence mining & Material culture & Relative chronology \\
\hline $\mathrm{O1}$ & Candalares & $\mathrm{T}, \mathrm{E}$ & Mar, CP, CR, ML, EP & PR-EB, R \\
\hline $\mathrm{O} 2$ & Peñón del Águila & $\mathrm{T}, \mathrm{P}, \mathrm{G}, \mathrm{E}$ & Mi, CMPR, ML & PR-EB y PRO \\
\hline $\mathrm{O} 3$ & Barranco Valpeñoso & $\mathrm{S}, \mathrm{E}, \mathrm{P}$ & Mi, Mar, CMR, ER & PR-EB, R \\
\hline O4 & Revuelta Molinicos & $\mathrm{T}, \mathrm{E}$ & Mi, Mar, ML & PR \\
\hline $\mathrm{O5}$ & Los Castellones & T.E & Mi, Mar, & $\mathrm{PR}$ \\
\hline 06 & Arroyo de la Grieta & T.E & Mi, Mar, EP & PR-EB \\
\hline 07 & Mingorramos & $\mathrm{T}, \mathrm{E}, \mathrm{G}$ & $\mathrm{Mi}, \mathrm{Mar}, \mathrm{CR}$ & $\mathrm{PR}, \mathrm{R}$ \\
\hline 08 & Navalasno & $\mathrm{T}, \mathrm{E}$ & Mi, Mar, ER & $\mathrm{PR}, \mathrm{R}$ \\
\hline 09 & Nava de la Cabrera & $\mathrm{T}, \mathrm{E}$ & Mi, Mar & PR \\
\hline 10 & Las Minetas & $\mathrm{T}, \mathrm{E}$ & Mi, Mar & $\mathrm{PR}$ \\
\hline 11 & Las Minetas II & $\mathrm{T}, \mathrm{E}, \mathrm{S}$ & Mar & PR \\
\hline 12 & Laguna de los Llanillos & $\mathrm{T}, \mathrm{E}$ & Mi, Mar & $\mathrm{PR}$ \\
\hline 13 & Casa mina de Valquemado & $\mathrm{T}, \mathrm{E}$, & Mi, Mar & PR \\
\hline 14 & Casa vieja de Valquemado & $\mathrm{T}, \mathrm{E}$ & Mi, Mar, & PR \\
\hline 15 & Cerro de los Venados & $\mathrm{T}, \mathrm{E}$ & Mar & PR \\
\hline 16 & Los Escoriales & $\mathrm{T}, \mathrm{E}, \mathrm{Es}, \mathrm{P}, \mathrm{S}$ & Mi, Mar, ER, CR & $\mathrm{PR}, \mathrm{R}$ \\
\hline 17 & Arroyo Aliseda & $\mathrm{T}, \mathrm{E}$ & Mi, Mar & PR \\
\hline 18 & Arroyo Fresnedillo & $\mathrm{T}, \mathrm{E}$ & Mi, Mar, & PR \\
\hline 19 & El Polígono & $\mathrm{T}, \mathrm{E}, \mathrm{S}, \mathrm{P}$ & Mi, Mar, ML & PR-C, PR-EB \\
\hline 20 & José Palacios-Dña Eva & $\mathrm{T}, \mathrm{P}, \mathrm{G}, \mathrm{E}$ & Mi, Mar, CMP, CPR-EB, CR & PR-EB, PROT, R \\
\hline 21 & Mina Arrayanes & $\mathrm{T}, \mathrm{E}$ & Mi, Mar, CR & $\mathrm{PR}, \mathrm{R}$ \\
\hline
\end{tabular}

Tab. 1. Mining exploitations in eastern Sierra Morena Mountains. Mining evidence: T trench, P mining shaft, S survey/pit, G Gallery, E mining dump. Material Culture: Mi Mineral, Mar Hammer, ML lithic material, CP Prehistoric pottery, CR Roman pottery, CPR Protohistoric pottery, CMP Prehistoric metallurgical pottery, CMPR Protohistoric metallurgical pottery, CMR Roman metallurgical pottery, EPR Late prehistoric slag, ER Roman slag. Chronology: PR-C Late Prehistory, Copper Age, PR-EB Late Prehistory, Bronze Age, PRO Protohistory and R Roman (from Arboledas et al. 2017.52). 


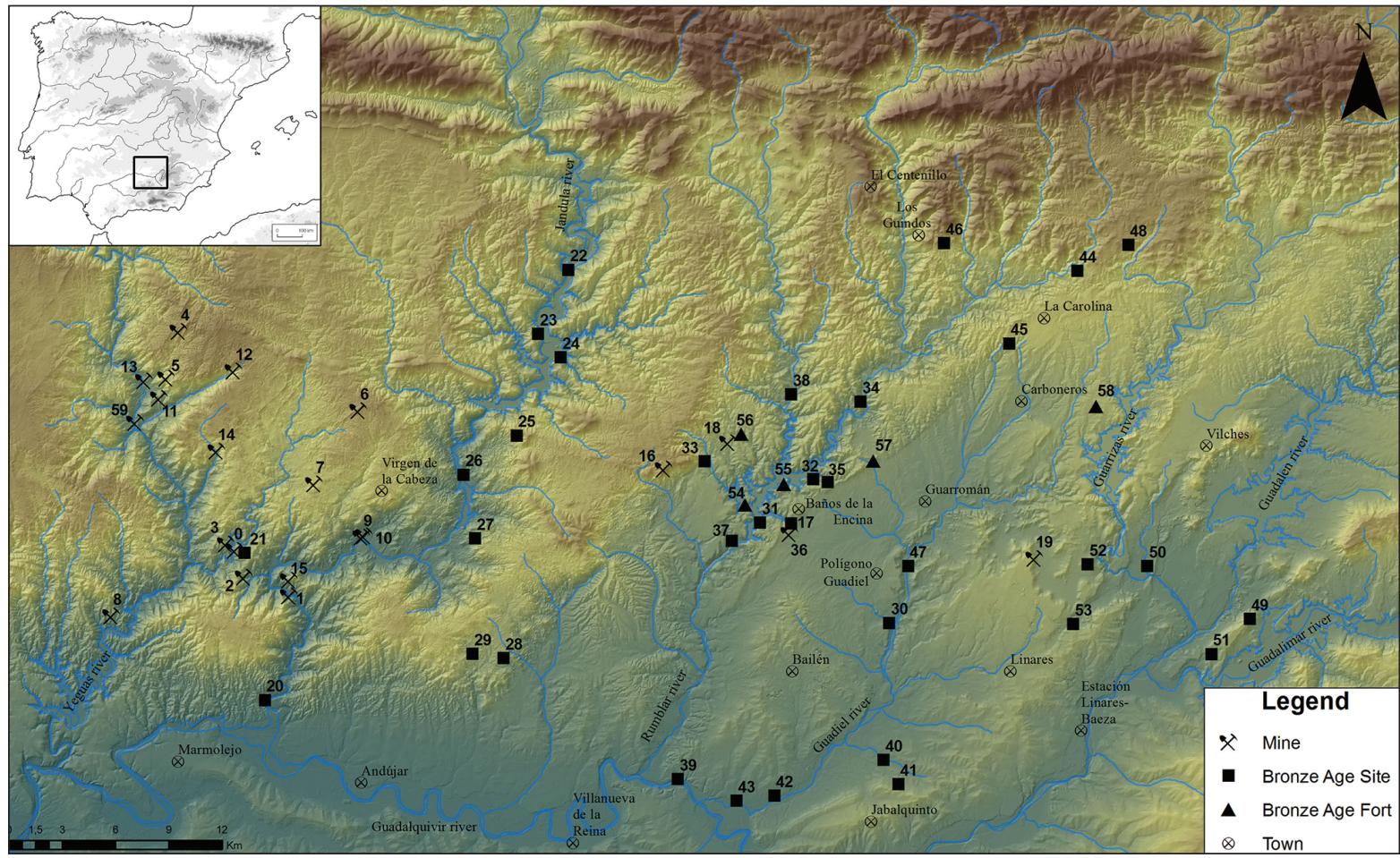

Fig. 1. Map with prehistoric mines and Bronze Age settlements in eastern Sierra Morena Mountains. o Los Candalares, 1 Peñón Águila, 2 Barranco Valpeñoso, 3 Revuelta Molinicos, 4 Los Castellones, 5 Arroyo Grieta, 6 Mingorramos, 7 Navalasno, 8 Nava de la Cabrera, 9 Las Minetas, 10 Las Minetas II, 11 Laguna Llanillos, 12 Casa Valquemado, 13 Cerro los Venados, 14 Arroyo Aliseda, 15 Fresnedillo, 16 Salas de Galiarda, 17 Poligono, 18 José Palacios, 19 Arrayanes, 20 Cabrerizas, 21 Candalares, 22 Contadero, 23 Valtravieso, 24 Atalayón, 25 La Lancha, 26 Casa Peral, 27 Lagunilla, 28 Cerro Tornero, 29 Cerro Atalaya, 30 Cerro Buenaplata, 31 Peñalosa, 32 Verónica, 33 Los Castillejos, 34 Cerro de la Atalaya, 35 Basurero, 36 Castillo de Baños de la Encina, 37 Cerro de las Obras, 38 La Majada, 39 Sevilleja, 40 Ctjo. Sancho, 41 Fuente Nueva, 42 Est. Espeluy, 43 Guadiel Norte, 44 El Castillo, 45 Torrecillas, 46 Cerro Castellones, 47 Cerro Pelao, 48 Cerro del Cura, 49 Giribaile, 50 Piélago, 51 Atalayuela, 52 Cerro de las Casas, 53 Castro Magdalena, 54 Morquigüelo, 55 Piedras Bermejas, 56 Cerro Burraca, 57 Ctjo. Salcedo, 58 Cerro Barragán, 59 Casa Vieja Valquemado (map by M. I. Roger and L. Arboledas).

oxides (cuprite, azurite, malachite, etc.), and polymetallic ores were exploited, as well as some native silver, which were present in the upper levels of the mineral seams. This is the case of the Peñalosa (Baños de la Encina, Jaén) site, in which compositional analysis indicates the use of minerals from two polymetallic mine groups: one with cupriferous ores, copper being the dominant metal (José Palacios and Salas de Galiarda mines), and another with lead-cupriferous ores (Polígono mine) (Moreno et al. 2010; Moreno, Contreras 2010.60).

The main problem in studying prehistoric mining operations lies in identifying them, as in most cases, subsequent workings, especially in the industrial era, have obscured, altered or destroyed the earlier remains. This being said, during the last fieldwork season carried out in the eastern Sierra Morena, we were able to identify the remains of 21 mines, most of which were unknown until now. Material culture, mainly stone tools and pottery from Late Prehistory, was documented (Tab. 1; Fig. 1) (Arboledas et al. 2017.52-53).

As mentioned above, the documented mining tended to work veins with cupriferous mineralizations found in granite outcrops situated to the north-west of Baños de la Encina, Linares and Sierra de Andújar. More specifically, two mines were found in the Rumblar Valley, one in Linares, while the other 18 were distributed along the valleys of the Jándula and Yeguas rivers (Andújar). The mines were open cast, mainly in the form of trenches and shallow galleries, exploiting surface outcrops rich in oxide and carbonated copper minerals, with an almost certain presence of some native copper. Prehistoric miners would have been able to recognize easily the veins on the surface thanks to the white colour of the quartzite outcrops, with streaks of minerals such as azurite (blue), malachite (green) or copper 
in them. On some of the trench walls, it is still possible to see the remains of cupriferous mineralizations, mainly malachite (Arboledas et al. 2017.52).

This type of open-cast work leaves irregular traces and variable spaces as a result of the exploitation of the richest parts of the veins. These are typical traces of the systematic, small-scale 'pillage mining' carried out in antiquity, even in the contemporary epoch. The morphology and dimensions of the trenches depend on the direction and thickness of the mineralizations, the location of the mineral, its thickness and other physical and geological conditions. Consequently, trenches longer than $50 \mathrm{~m}$ and with widths of up to $6 \mathrm{~m}$ have been found at the Polígono, Los Candalares and Navalasno mines, as well as smaller mines measuring approximately $10 \mathrm{~m}$ long, $3.5 \mathrm{~m}$ wide and $10 \mathrm{~m}$ deep, such as those documented at the José Martín Palacios mine (Figs. 2 and 3) (Arboledas et al. 2017.53).

Each one of the 21 mines documented in this region are composed, on the one side, by what remains of the open-air working activity and, on the other, by

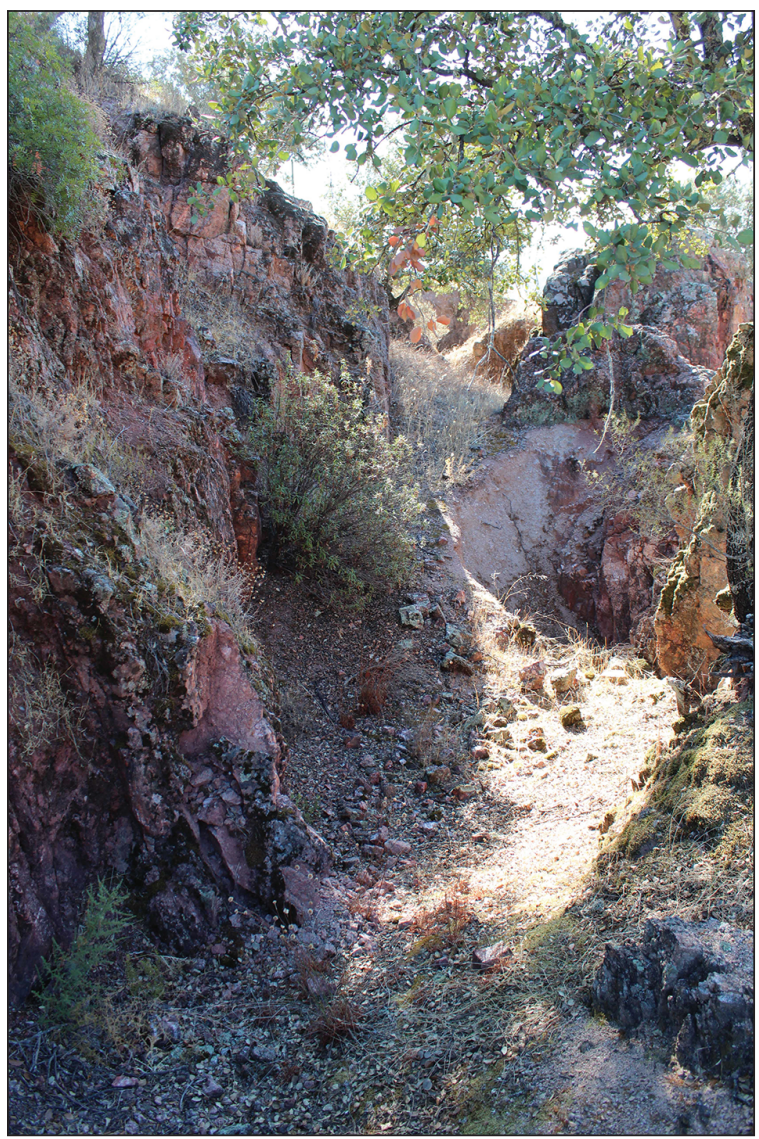

Fig. 2. Trench at the prehistoric mine of Las Minetas (Lugar Nuevo, Andújar) (photo: L. Arboledas and Peñalosa Project). appended slag dumps that may be very integrated into the landscape or, on the contrary, could be considerably altered because of exploitation dating to the Industrial Epoch. Both inside and outside the mine, material culture corresponding to the different phases of exploitation of these mines has been identified. But, above all, numerous stone tools used to extract and grind the minerals were found. They are mainly ophite and diorite mallets and hammers, some stone bowls, polished adzes, hand-mills and mills (Fig. 4). The hammer-mallets found complete or almost complete had grooves in their middle for handles. The differences in morphology and weight are important with regard to functional interpretations. Hammers of average weight (0.8 to $5 \mathrm{~kg}$ max.) were used for both direct and indirect percussion. Their typology is similar to mining hammers found at other mines, such as those in south-western Iberian Peninsula (Hunt 2003; Blanco, Rothenberg 1981) and the area of Asturias-León (Blas-Cortina 2007-2008). The large hammers (over 5kg) are thought to have been used in slinging structures placed directly in front of the rock (Blas-Cortina 2007-2008; Pickin, Timberlake 1988.Fig. 2a). These large hammers could also have been employed to extract mineral with the help of some kind of leverage system similar to a shadoof used to obtain water from wells (Fig. 4.1) (Arboledas et al. 2017.54).

A first petrographic analysis of the objects confirms that most of the tools were made of intrusive igneous rocks with a very hard ophitic composition. The tools have naturally smooth surfaces, common in typical boulder-type supports. This means that the raw materials used to produce these artefacts must have come from secondary deposits, not from primary outcrops. Many ophite stones can be found in the streambeds (the Yeguas or Cabrera rivers) near the mines, evidencing clearly which areas were used to obtain these raw materials. The identification of a hammer with a groove among other stones in the bed of the Cabrera River (Andújar) during a survey of the Jandula Valley could confirm that nearby riverbeds were the provenance of these tools (Fig. 4.3).

The tools used to prise out the minerals were probably made of bone or deer antler and wood, although no remains of such tools have been found or evidenced in mines in south-east Iberia. However, we do have evidence of the use of fire to facilitate the extraction of mineral from seams, a practice that is well established in other sites in Europe, such as in the mines at Copa Hill and Cwmystwyth in Wales 


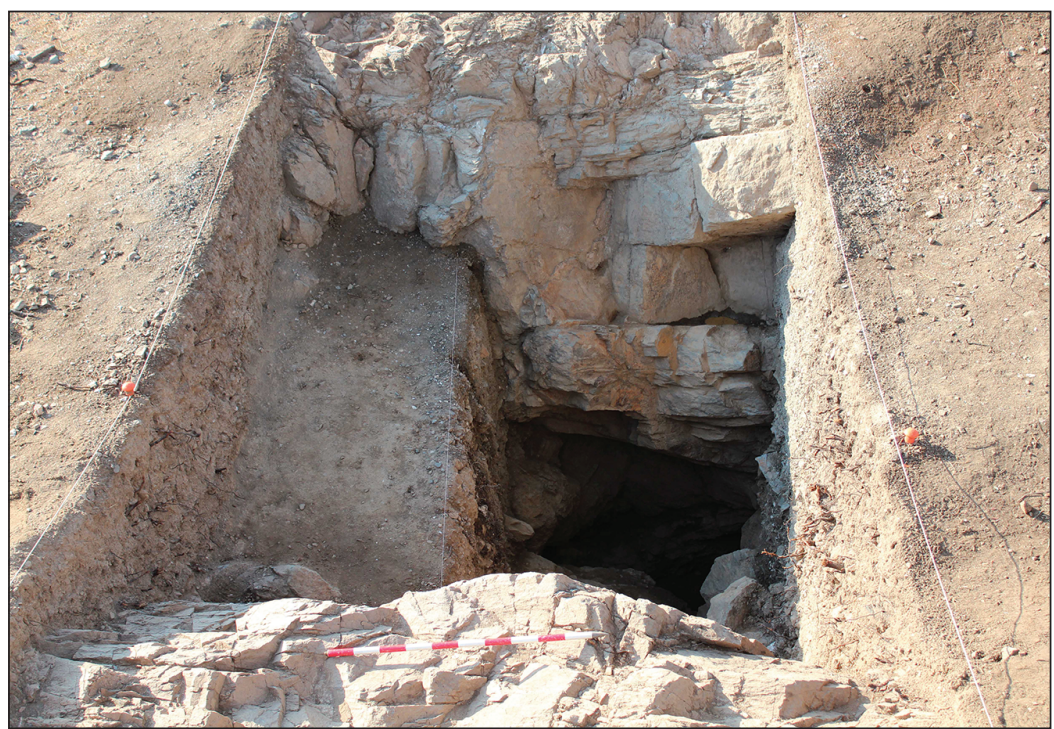

Fig. 3. Trench 1 of the José Martin Palacios mine (Baños de la Encina) after its excavation (photo: L. Arboledas and Peñalosa Project).

link between the mining and nearby prehistoric settlements, and, above all, the material culture found in the dumps and trenches. The most significant elements are lithic artefacts, mainly mining hammers, as well as various pottery objects. The identification of only one of these factors cannot be ascribed per se to a certain period, but the combination of different aspects and data, such as excavation or isotopic analysis, can help in the chrono-cultural identification of mining-metallurgical activities.

Most of the evidence we have so far identified allows us merely

(Timberlake 2003) or Pioch Farrus IV in Cabrières, France (Castaing et al. 2005). The first evidence found in south-east Iberia is at the mine at José Martín Palacios (Baños de la Encina). A blackish stain was found on the southern quartzite wall of Trench 1 , as a result of the method of heating the rock with fire in order to extract the mineral (Arboledas et al. 2015.150). The second evidence is indirect, and comes from the Polígono mine (Arboledas, Contreras 2010). In the Argaric settlement of Peñalosa, mineral fragments from that mine have been identified that showed abundant fissures in which bubbles could be observed. These features are evidence that the mineral was exposed to relatively high temperatures without making the ore melt (Moreno et al. 2010.309-310).

In short, the prehistoric mining found in this region is characterized by the exploitation of open-air mines (trenches and open-pit) that do not require largescale infrastructure. On the contrary, underground mining needs more means such as lighting, wells and access galleries, among others. This exploitation system, as well as some of the techniques employed, e.g., the use of fire, have survived throughout ancient times until the $20^{\text {th }}$ century, due to its simplicity and profitability.

\section{Current issues in dating prehistoric mines}

The aforementioned twenty-one mines are considered to date from Late Prehistory due to several archaeological indicators: the typology of the mining work, the technology used for mine exploitation, the to ascribe these exploitations to Late Prehistory (Copper and Bronze Ages) or the Iron Age. For example, stone tools, especially hammers, are the main dating element documented in mines. However, these hammers offer only general information about these contexts, as they could be found in different mining archaeological records throughout the Iberian Peninsula and Europe, and can be traced from the Copper Age to the Late Bronze Age (Ambert et al. 2009; Blas-Cortina et al. 2013; Blanco, Rothenberg 1981. lam. 30; Timberlake 1990). Variations in their typology cannot normally be used as chronological identifiers (Hunt 2003).

Characteristic Argaric pottery, fragments of deep crucibles and immature slag with the same characteristics as those documented at different Argaric settlements in this region have been found at four mines (Candalares, Arroyo la Grieta, Peñón del Águila and José Martín Palacios). They are indisputable indications that these mines were at some point exploited during the Argaric Bronze Age. Other indicative elements are the flint flakes found in Trench 5 at José Martín Palacios and another found in a small dump at the Polígono mine (Fig. 5). These flint flakes can be linked to a Copper Age and/or Early Bronze Age mining phase (Arboledas et al. 2015; Arboledas, Contreras 2010).

In two of the twenty-one cases, the José Martín Palacios and Polígono mines, Bronze Age exploitation is clearly identified thanks to indirect information from lead isotope analyses. The correspondence of the isotopic fields of these two mines with miner- 
als and the two copper ingots found at Peñalosa confirms that both were worked during the Bronze Age. Aside from this fact, analyses have also shown that there was at least one other mine supplying raw material to this settlement (Hunt et al. 2011.198-201).

The only radiocarbon dates for prehistoric mining in the south-east are those obtained from the Cerro Minado (Huercal-Overa) and José Martín Palacios mines (Baños de la Encina) (Tab. 2). In the first case, the mining was dated to the late Copper Age (Delgado et al. 2014.30). In the second, we have three different, although not contradictory, dates. They confirm the results of the fieldwork and lead isotope analyses, showing that mining took place both during the Bronze Age and subsequently. The first evidence of mining at this site, or at least the first that could be identified in Trench 1, dates from the Early Bronze Age (CNA-1004). This date was obtained from a carbonized sample found in the first and deepest stratum, which corresponds with the gangue dump generated during the mining, and which was associated with Bronze Age pottery. The chronology given by the other two charcoal samples date respectively two fill layers corresponding to the interior of Trenches 1 and 2 once mining activities were no longer in operation. Although, these dates are an indication that this mine could have been frequented and exploited during the Protohistory (Arboledas et al. 2015).

To summarize, of the 21 mines identified as prehistoric, two of them, José Martín Palacios and Polígono, present a clear Bronze Age exploitation phase. Another three mines have been dated to the Bronze Age from the Argaric material culture identified at them. The remainder have been classified as mines exploited during Late Prehistory. The existence of a large number of metallurgical settlements in the Bronze Age leads us to believe that the mines were being worked during this period, although we are still not able to specify their exact chronology. The Iberian Peninsula has other examples of pre-Iron Age mines. Most of them are in the Asturias and León regions, and include mines such as El Aramo and $\mathrm{El}$ Milagro (Asturias) and La Profunda (León) (Blas-Cortina 2007-2008; Blas-Cortina et al. 2013). We can also add the mines of Moçissos in Portugal (Hanning et al. 2010.289), those of the south-western Iberian Peninsula (Hunt 2003) and Sa Mitja Lluna on Illa de Colom (Menorca) (Hunt et al. 2014). Outside of the Peninsula, we could highlight, among many others, the prehistoric mining exploitations of Cabrières (Ambert et al. 2009) or Ross Island (O'Brien 2004).

\section{The control and exploitation of a mining terri- tory: metallurgical villages and working areas or mining camps?}

The exploitation of mineral resources in the eastern Sierra Morena Mountains directly and indirectly affected both the landscape and the settlement pattern of this area. The first significant evidence of occupation of this region dates to the Chalcolithic, with settlements such as Siete Piedras and Cerro del Tambor (Baños de la Encina, Jaén). They were probably linked to the exploitation of the nearby copper mines at Salas de Galiarda and Polígono, respectively. It was during this period that the mines began to be worked, as attested at Polígono mine (Arboledas, Contreras 2010).

However, it is in the Bronze Age that we see a genuine 'colonization' of the eastern valleys of the Sier-

\begin{tabular}{|c|c|c|c|c|c|c|c|c|}
\hline $\begin{array}{l}\text { Laboratory } \\
\text { code }\end{array}$ & Mine & Material & Context & $\begin{array}{c}\text { Conven- } \\
\text { tional } \\
\text { date BP }\end{array}$ & \pm & $\begin{array}{l}\delta^{13 C} \\
(\%)\end{array}$ & $\begin{array}{l}\text { Date calibrated } \\
(1 \sigma)(68 \% \\
\text { probability })\end{array}$ & $\begin{array}{l}\text { Date calibrated } \\
\qquad(2 \sigma)(95 \% \\
\text { probability) }\end{array}$ \\
\hline CNA-1004 & $\begin{array}{c}\text { José } \\
\text { Martín } \\
\text { Palacios }\end{array}$ & $\begin{array}{c}\text { Rosacea } \\
\text { coal }\end{array}$ & $\begin{array}{c}\text { UEN 6, layer } \\
\text { lower of the } \\
\text { slag heap, } \\
\text { Trench 1-Sector } 7\end{array}$ & 3726 & 31 & -16.74 & $2196-2029 \mathrm{cal} \mathrm{BC}$ & $2205-2030 \mathrm{cal} \mathrm{BC}$ \\
\hline CNA-1017 & $\begin{array}{c}\text { José } \\
\text { Martín } \\
\text { Palacios }\end{array}$ & $\begin{array}{c}\text { Rosacea } \\
\text { coal }\end{array}$ & $\begin{array}{l}\text { UEN 12, inside } \\
\text { Trench 1-Sector } 1\end{array}$ & 2359 & 41 & $-21,29$ & $488-389 \mathrm{cal} \mathrm{BC}$ & $\begin{array}{l}730-691 \mathrm{cal} \mathrm{BC} \\
659-651 \mathrm{cal} \mathrm{BC} \\
543-366 \mathrm{cal} \mathrm{BC}\end{array}$ \\
\hline CNA-4006 & $\begin{array}{c}\text { José } \\
\text { Martín } \\
\text { Palacios }\end{array}$ & $\begin{array}{c}\text { Rosacea } \\
\text { coal }\end{array}$ & $\begin{array}{c}\text { UEN 6, superficial } \\
\text { level Trench } \\
\text { 2-Sector } 4\end{array}$ & 2695 & 32 & $-18,85$ & $894-810 \mathrm{cal} \mathrm{BC}$ & $903-805 \mathrm{cal} \mathrm{BC}$ \\
\hline MAMS-18508 & \begin{tabular}{|c|} 
Cerro \\
Minado
\end{tabular} & $\begin{array}{c}\text { Coal } \\
\text { Pistacia sp. }\end{array}$ & North slag heap & 3905 & 21 & & $2466-2347 \mathrm{cal} \mathrm{BC}$ & \\
\hline
\end{tabular}

Tab. $2 .{ }^{14} \mathrm{C}$ dates from prehistoric mines in the south-eastern Iberian Peninsula (Arboledas et al. 2015; Delgado et al. 2014). 
ra Morena, with the founding $e x$ novo of medium-sized settlements ( $<1$ ha) such as Peñalosa in Baños de la Encina, Cerro Pelado in Linares and Las Cabrerizas in Marmolejo. These settlements occupied strategic positions with extensive territorial control of the mineral valleys, and they all have remains attesting copper-based metallurgical activity. Near these settlements, there is a series of small forts (e.g., Piedras Bermejas) with a dual function: to enhance the interconnection between settlements and to provide greater control of the natural passes between the Guadalquivir Valley and the inner valleys of the eastern Sierra Morena Mountains. During this period, these societies evolved towards a more stratified model, with stronger political control (Lull 1983; Chapman 2008). It has been proposed that the reason for this 'colonization' was the presence and exploitation of the copper and silver mineral resources, which were redirected towards the large political centres in the Guadalquivir and Guadalimar valleys (Baeza and Úbeda) (Lull 1983; Contreras 2000; Contreras, Cámara 2002).

This intensive occupation appears to be linked to an expansion of mining, which is documented at
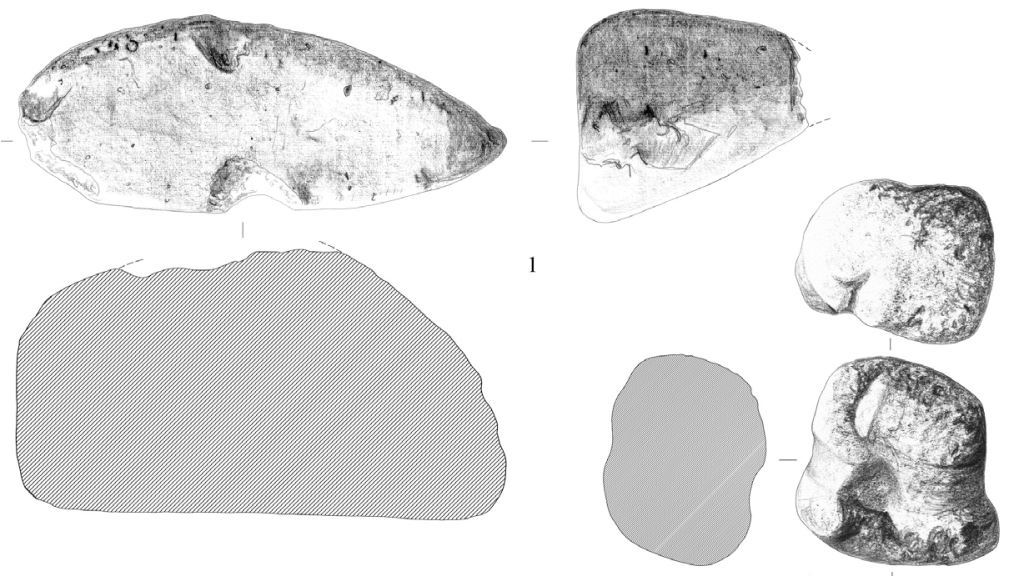

3
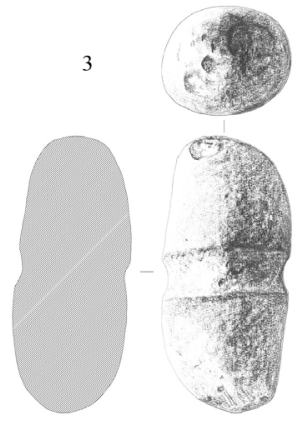

4
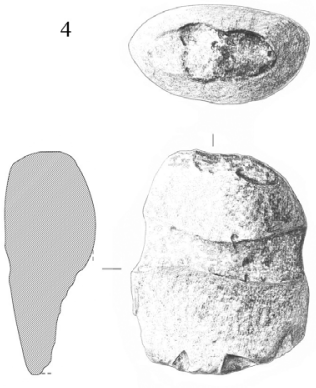

2
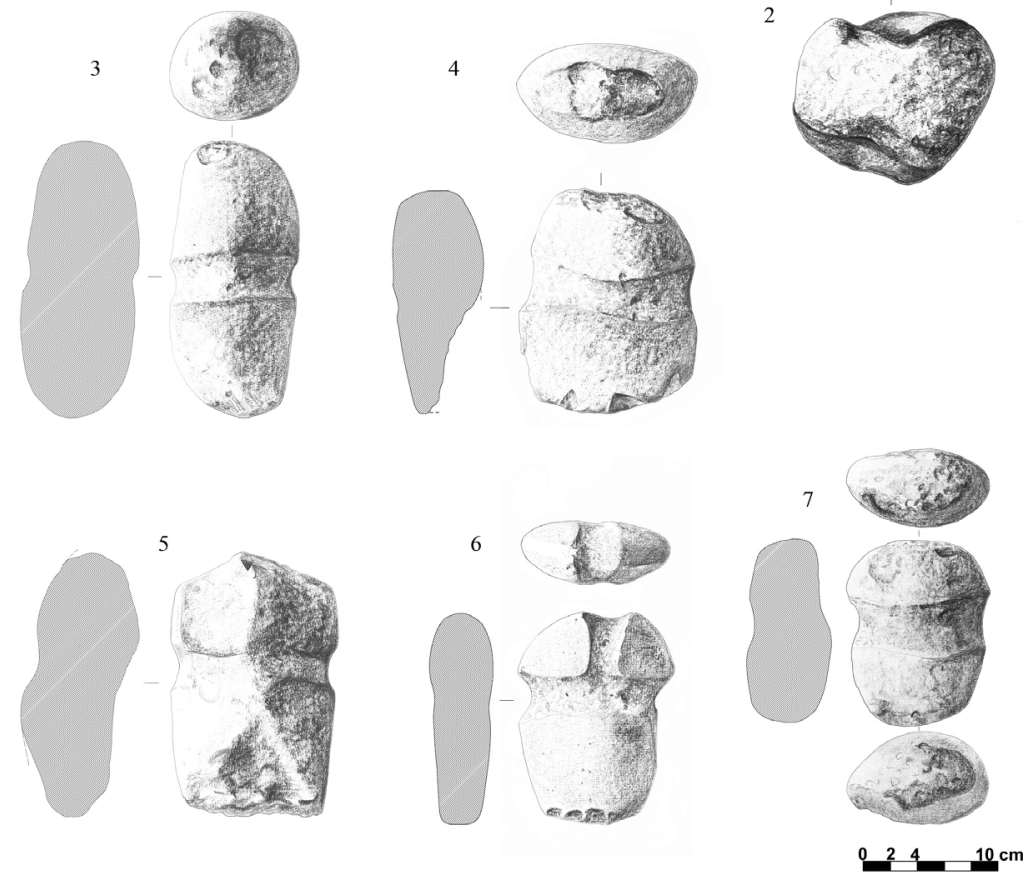

Fig. 4. Mining hammers with central grooves from the prehistoric mines of eastern Sierra Morena: 1 El Polígono, 2 José Martin Palacios, 3 Río Yeguas, 4 and 6 Los Candalares, 5 Arroyo de la Grieta, 7 Polígono (elaborated by Luis Arboledas.)

the Polígono and José Martín Palacios mines, and, therefore, to an increase in metal production. Copper mining and production appears to have been the basis of the distribution and correlation of settlements, which evidence a hierarchical organization (Contreras, Cámara 2002). Although the location of settlements does not appear to be directly linked to the spatial distribution of the mines or their exploitation, as has been confirmed in the Rumblar Valley, they do seem to be related to the territorial control of natural passes and to the processing, production and distribution of metal (Jaramillo 2005. 474).

The entire production process of copper-based metallurgy, from the extraction of the mineral to the creation of the final metal item (objects and ingots) has been documented archaeologically in excavations of Argaric settlements at Peñalosa and Castillo de Baños de la Encina, both in the Rumblar Valley. Material remains of metallurgy (mineral, slag, crucibles, etc.) have also been found in the majority of the Argaric settlements located in this valley (Contreras 2000). Vestiges of metallurgical production have been documented in most of the domestic units (slag, minerals, crucible-furnaces, melting pots, etc.). They are in roofless areas, co-existing and sharing space with other productive activities, such as the storage of grain and other foodstuffs, food preparation and consumption, spinning and weaving, pottery making, the manufacture of cork, wood and bone objects, etc. (Alarcón 2010). However, in the 

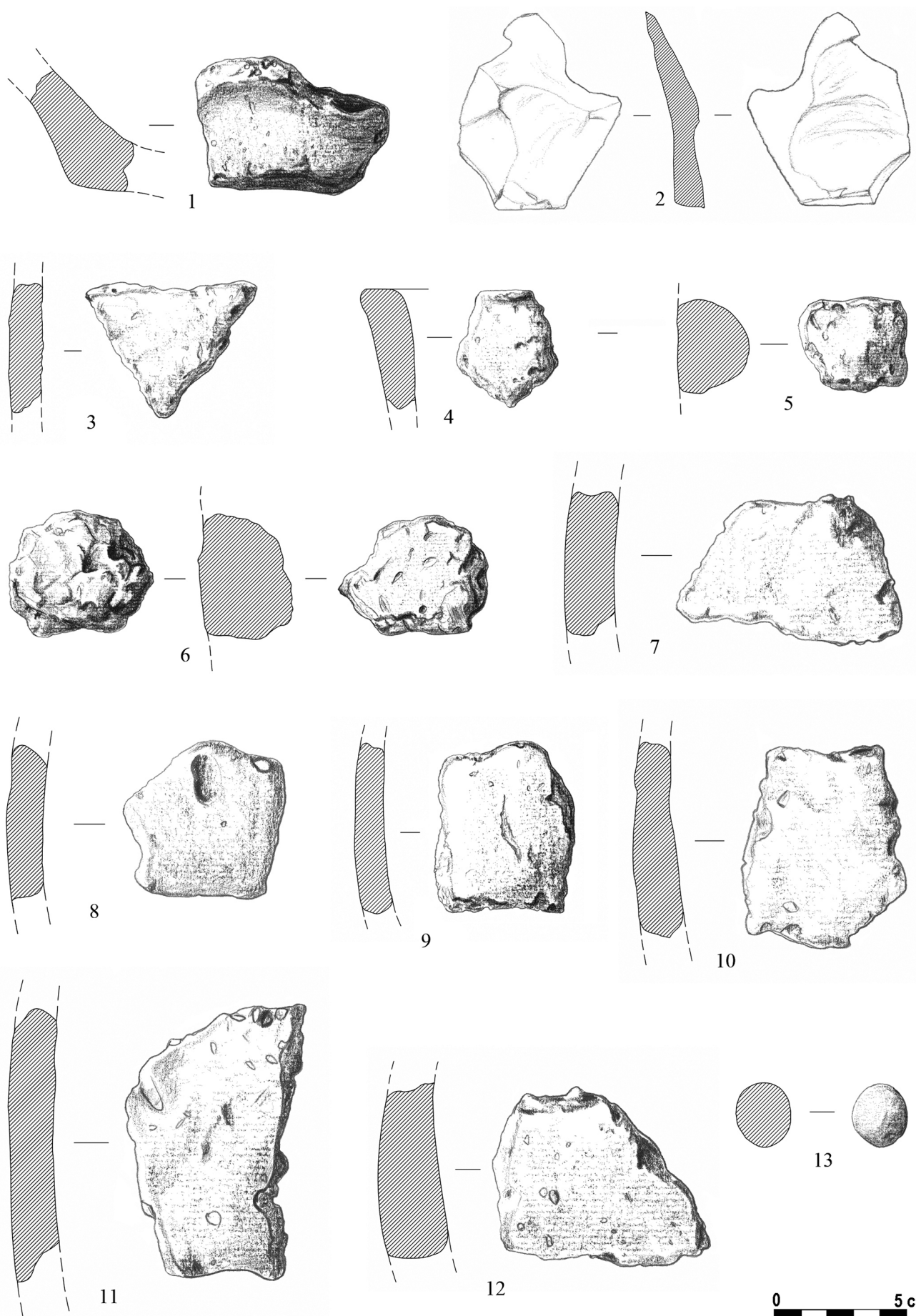

12

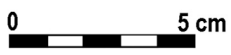

Fig. 5. Bronze Age material culture from the mines and working areas documented in eastern Sierra Morena Mountains: 1, 3-5, 9 Argaric ceramic, 2 flint shards, 6 technical ceramic, 13 clay ball, José Martín Palacios mine; 10-12 Bronze Age ceramics, Peñón del Águila; 8 Bronze Age ceramics, Candalares (elaborated by $L$. Arboledas).

most recent excavation campaigns at Peñalosa, a metallurgical waste dump was found outside the walled precinct. This is the first late-prehistoric site with such evidence, and it indicates the importance of metallurgy in daily life, as well as the presence of different phases of the metallurgical process beyond the residential areas of the site (Contreras et al. 2014).
Recent excavations at the José Martin Palacios mine and the archaeo-mining survey of the Sierra de Andújar Mountains have contributed important data regarding the existence of possible working areas near the mines, with evidence of metallurgical activities. This is the case of Candalares, Revuelta de los Molinicos and Arroyo de la Grieta, in the Upper Yeguas 
River basin. Judging from the size of these new sites, they do not seem to be settlements such as those documented in other areas of the Jándula or Rumblar Valleys, but rather small, multifunctional workshops, where the main activity would have been mineral extraction and processing. The identification of immature slag, hand-mills and grooved hammers at two of these sites indicates that such specialised activities were carried out adjacent to the mines (Arboledas et al. 2017). Parallels to this kind of site have been identified at Loma de Tejerías (Albarracín) (Montero, Rodríguez 2008) and Les Campa de Mines (Sierra del Aramo) (Blas-Cortina et al. 2013).

Two fragments of technical vessels have been documented at the Jose Palacios mine, one of which (Archaeological Survey 2) (Fig. 5.6), with an adhered slag layer, was found in the oldest stratigraphic level next to several fragments of Argaric pottery. This level could have been associated with a multifunctional area in which the miners from nearby Argaric settlements would have undertaken various daily activities alongside major mining and metallurgical tasks. On a structural level, this case is very different from previous examples, as no structures that would differentiate one space from another have been identified. Therefore, it seems we are dealing with different situations, or at least with other ways of organizing work and space, perhaps due to the large number of metallurgical settlements in the Rumblar Valley (Arboledas et al. 2015.155-156).

This is the first evidence of metallurgical working spaces at prehistoric mines in the south-eastern Iberian Peninsula; activities which, based on our current knowledge of the subject, must have been completed with the different metallurgical phases are documented at settlements such as Peñalosa (Moreno, Contreras 2010). To explain the presence of slag fragments and crucible-furnaces, we offer two possible hypotheses, having previously taken into account, on the one hand, that only a small area was excavated at the José Palacios mine and, on the other, that the remaining data come from archaeological surveys. The first hypothesis is that these objects could be related to trial smelting to ascertain the quality of the mineral, and the second could be related to minor but frequent metallurgical activity carried out at the mine, especially in the case of the Candalares mine. In any case, the practice of metallurgical activities, as well as the existence of working areas near the mines, would have depended on certain factors, such as the mines' location and their proximity to a settlement (Arboledas et al. 2017).
Other evidence of metallurgical activity in the Late Prehistory of the Iberian Peninsula has been identified at the Moçissos mine (Portugal) (Hanning et al. 2010.289) and the aforementioned camps of Les Campa de Mines in the Sierra del Aramo (Riosa, Asturias) (Blas et al. 2013) and Loma de la Tejerías in Albarracín (Montero, Rodríguez 2008.163). In the latter two cases, the mines are located in isolated areas atop high mountains, far from the region's main settlements. This fact explains why camps were set up near the mines, especially in the case of Les Campa de Mines, which is more than $2000 \mathrm{~m}$ a.s.l. The mineral would have been processed at these camps, as proven by the existence of metallurgical remains, with the aim of obtaining the metal in situ to make it easier to transport to the settlements.

The settlement patterns in the regions where the aforementioned camps were located are very different from those documented in the mining valleys of the eastern Sierra Morena Mountains. For example, in the Rumblar Valley, a large number of Argaric settlements are located near mines $(>3 \mathrm{~km})$. This would have made seasonal mining camps unnecessary, as a person would have been able travel to and from the mine in less than a day. Nevertheless, this does not rule out the possibility that at certain times people could have stayed at the mine for a few days, which would explain the domestic archaeological remains found at the José Palacios mine (Baños de la Encina). On the other hand, in the Sierra de Andújar (Jándula and Yeguas valleys), the mines are in isolated areas, long distances from the Bronze Age settlements located to date, which could explain the presence of these camps or workshops (Arboledas et al. 2017).

\section{The scale of metal production and its distribu- tion}

The excavation of the metallurgical site of Peñalosa has so far yielded more than $20 \mathrm{~kg}$ of slag and $95 \mathrm{~kg}$ of metallurgical pottery. This volume exceeds the total metallurgical evidence found at all the other Late Prehistoric sites on the Iberian Peninsula. This data, added to the twenty-one newly identified prehistoric mines and about twenty settlements with metallurgical remains, clearly reflects the high volume of production at this site in particular and in the whole of the eastern Sierra Morena Mountains in general. This scale of production would have exceeded the demand from this region, and implies the exchange/distribution of metal on a supra-regional scale. All this evidence, as well as the presence of 
ingots, an indication of the amassing of metal for storage and trade, justifies the definition of this site as a metallurgical settlement that specialised in copper production (Moreno, Contreras 2010.56-58; Moreno et al. 2017).

Lead isotope analyses have proven to be the best technique for identifying or ruling out areas supplying and distributing minerals. In the South-East, more than a hundred lead isotope analyses of minerals, metallurgical elements and copper and silver objects belonging to both prehistoric mines and settlements dated to the Bronze Age (Argaric Culture) have been published to date (Stos-Gale 2001; OXALID; Hunt et al. 2011; Bartelheim et al. 2012.Tab. 6; Murillo, Montero 2014; Murillo et al. 2015). For the Upper Guadalquivir, 34 analyses have been carried out so far, with samples from the settlement of Peñalosa (21), the José Martín Palacios mine (7) and the Polígono mine (6). The results of all these analyses suggest that, for the most part, the samples from Peñalosa are isotopically consistent with the Polígono (10 samples) and José Palacios mines' (2 samples) fields. However, some of the Peñalosa samples come from a different mine that has yet to be isotopically characterized (Hunt et al. 2011.197-201).

For the remainder of the Iberian south-east, we have a total of 79 analyses of copper and silver objects from various Argaric sites (Bronze Age), most of them from funerary contexts. To date, 53 analyses of copper objects from the sites of El Argar, Fuente Álamo and Gatas in Almería, La Bastida, Cabezo Negro, Monteagudo and Rincón de Almendricos in Murcia, and Cuesta del Negro, Cerro de la Encina and Cerro de San Cristóbal in Granada have been published (Stos-Gale 2001; Stos-Gale et al. 1999; OXALID; Murillo et al. 2015). The number of analyses of silver objects is considerably lower. Only 26 objects have been analysed thus far from the sites of Cerro de la Encina (8 objects), Cuesta del Negro (5), Cerro de la Virgen (2), Terrera del Reloj (1) and Pantano de los Bermejales (1) in Granada, Peñalosa (8) in Jaén, San Antón (1) in Alicante, La Bastida (1) in Murcia and El Oficio (1) in Almería (Bartelheim et al. 2012.298-302, Tab. 6; Murillo 2013; Murillo, Montero 2014.214).

The results of the analyses of the copper objects from settlements in the South-East present a wide diversity of isotopic ratios in the metals. This indicates various origins, meaning that several copper mines were being worked. It has not been possible to determine the probable origin of more than half of the existing samples. This can be explained by the large number of small exploitations in the mining areas of Jaén, Granada and Almería that have not yet been defined. At present, the possible origin of only $32 \%$ of the samples (17 of the 53 analysed samples) has been determined (Tab. 3; Fig. 6). Eight objects show isotopic consistency with the Linares area and, more specifically, the Fuente Álamo dagger (FA1477-1) came from the Polígono mine; four objects came from the Los Pedroches mining district, two are connected to the Alcudia Valley, one with a mine in Alcolea, another with the district of Cartagena-Mazarrón, and the last with the mines of Santomera and Sierra de Cabrera (Montero, Murillo 2010. 44-46; Murillo et al. 2015.152-154, Fig. 11).

The isotopes show the wide diversity and dispersion of copper mineral sources. This fact rules out the hypothesis of a single large metal production centre (the Upper Guadalquivir) for the whole south-east of the Iberian Peninsula during the Argaric period. We actually have a much more complex picture in which other unidentified exploitations could have played an important role. However, it is very significant that from the high percentage of samples with a confirmed origin (17 of the analysed samples), eight of them (46\%) come from Linares. If the known evidence from the Valle de Alcudia and Los Pedroches is added, it becomes clear that copper from the central and eastern Sierra Morena, with $82.35 \%$ of the total, played a major role in the metallurgical

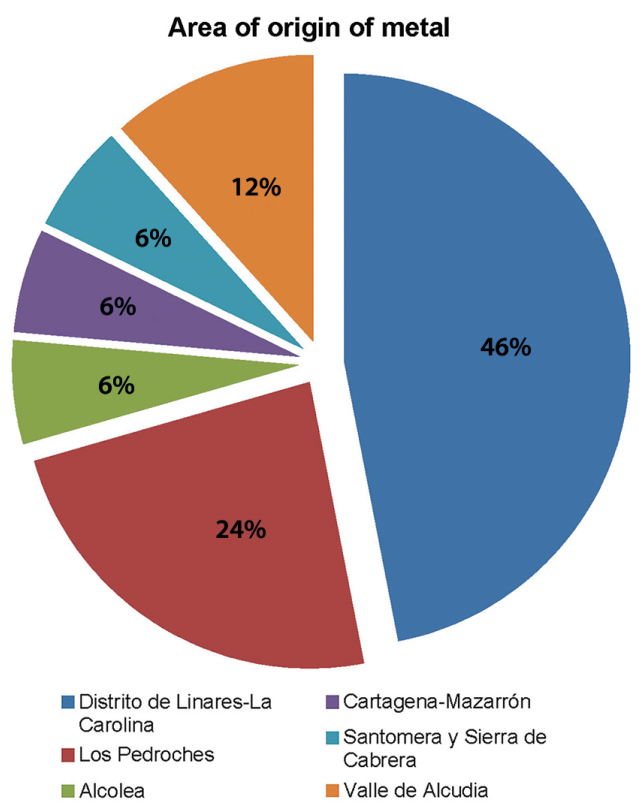

Fig. 6. Graph with percentages of each mining area with clear links to LIA analysis of objects from the Argaric sites of the South-East (elaborated by L. Arboledas). 
production of the south-east (Fig. 6). Thus, the analyses so far show that the Sierra Morena Mountains was the main production centre for the south-eastern Iberian Peninsula. This does not, however, rule out other sources, as can be seen from the isotopic results.

The development of silver metallurgy is one of the most characteristic innovations of Argaric society, when compared to previous periods. During this time, a large increase in the number of silver objects is documented (700 objects), which contrasts sharply with the rest of Europe during the second millennium BC and the Copper Age. Ornaments are the most common silver items, along with rivets used for swords, halberds and knives. Composition analyses of silver objects from several Argaric sites have proved the use of native silver rather than the cupellation technique used for lead sulfurs (Bartelheim et al. 2012; Murillo, Montero 2014).

Traditionally, it was thought that native silver came from three of the most important silver mines on the Iberian Peninsula: Herrerías (Almería), El Horcajo (Alcudia Valley) and Hiendelaencina (Guadalajara). However, lead isotope analyses of 26 silver objects from Argaric sites in the South-East show a different story: Bronze Age silver objects are isotopically remote from the south-eastern area and have more in common with the isotopic fields of Linares and the Alcudia Valley (El Horcajo). Native silver was traditionally obtained in both these geologically related areas, although in larger amounts from the Alcudia Valley than from Linares. The analyses also show that silver from mines in Almería and Cartagena would not have been used to manufacture artefacts found in Jaén and Granada. This seems logical, because of the mines' distance from those sites (Bartelheim et al. 2012.303-305). Less logical is the fact that silver from the Spanish Levant was not used even in the settlements of La Bastida (Murcia) and San Anton (Alicante). The only sample that bears a similarity to the isotopic area of the South-East is a ring from El Oficio (Murillo, Montero 2014.165).

These results show a similar panorama to the case of copper analyses, thus strengthening the idea that the central and eastern Sierra Morena would have been the main producer of copper and silver metals. In the case of silver, the analyses of sites in Jaén and Granada so far indicate that all the objects came from this region. However, more silver samples, particularly from the provinces of Murcia and Almería, need to be analysed to complete this panorama.

\section{Concluding remarks}

Our research in the Sierra Morena Mountains area is giving us new insights into the subject, and is allowing us to obtain a better image of the role of metallurgical production in the development of the prehistoric communities of the south-eastern Iberian Peninsula.

Thanks to the field and lab work of recent years, we have been able to identify and analyse 21 mines and date them to Late Prehistory (mainly the Bronze Age), thanks to the identification of the material cul-

\begin{tabular}{|c|c|c|c|c|c|}
\hline Site & ID & Object & Context & Metal & Area of origin of metal \\
\hline Cerro de la Encina & MO 39258 & Bracelet & Grave 21 & $\mathrm{Cu}$ & Linares \\
\hline Cerro de la Encina & MO 39279 & Bracelet & Grave 21 & CuAs & Linares \\
\hline Cerro San Cristóbal & OSC 7002 & Bracelet & Grave 12 & CuAs & Linares \\
\hline Fuente Álamo & FA 15/1477-1 & Dagger & Grave 58 & $\mathrm{Cu}$ & Linares \\
\hline Fuente Álamo & FA 12ž1494/6 & Dagger & Grave 54 & $\mathrm{Cu}$ & Linares \\
\hline Gatas & & & & $\mathrm{Cu}$ & Linares \\
\hline Gatas & & & & $\mathrm{Cu}$ & Linares \\
\hline Cabezo Negro & & & & $\mathrm{Cu}$ & Linares \\
\hline Cerro de la Encina & MO 39264 & Dagger & Grave 21 & CuAgSn & Los Pedroches \\
\hline Cerro de la Encina & MO 39257 & Awl & Grave 21 & CuAs & Los Pedroches \\
\hline Cerro de la Encina & MO 39261 & Bracelet & Grave 21 & CuAs & Los Pedroches \\
\hline Cerro San Cristóbal & OSC 15014 & Dagger & Grave 12 & CuAs & Los Pedroches \\
\hline Cerro de la Encina & MO 39255 & Bracelet & Grave 21 & CuSn & Alcolea \\
\hline Gatas & G 26 & Awl & G89-2B-14A1-Cd5 (M2) & $\mathrm{Cu}$ & Cartagena-Mazarrón \\
\hline Cerro de la Encina & $\mathrm{MO} 39281$ & Knife & Grave 21 & Cu? & Santomera y Sierra de Cabrera \\
\hline Cerro de la Encina & MO 55195 & Axe & Grave 18 & CuAs & Alcudia Valley \\
\hline Fuente Álamo & FA $600 / 5+33029$ & Dagger & Grave 52 & $\mathrm{Cu}$ & Alcudia Valley \\
\hline
\end{tabular}

Tab. 3. List of objects found at Argaric sites and their possible area of origin (based on Montero, Murillo 2010.44-46; Murillo et al. 2015; OXALID). 
ture and lead isotope and ${ }^{14} \mathrm{C}$ analyses. This is the largest known group of mines in south-eastern Iberia; in quantitative terms, its only peers elsewhere in Iberia are the major mining areas of Asturias and León (Sierra del Aramo, La Profunda, etc.), and in typological terms, those to be found in the province of Huelva.

The mining of copper and silver resources and their processing appears to have been a key factor in the intensive occupation and control of this region during the Early Bronze Age, when the number of settlements increased compared to the previous period. They were medium-sized settlements such as Peñalosa, La Verónica and Las Cabrerizas, of which the whole process of transforming mineral into metal has been archaeologically documented. Their locations would have been linked to territorial control, the processing and distribution of the metal, and the spatial distribution and exploitation of the mines.

One of the most important facts is the evidence of metallurgical tasks being carried out adjacent to the mines in three different cases, being the first time that this feature has been identified in southern Iberia. The purpose of these sites has been explained as metallurgical trials or occasional smelting. In some cases, such as Candalares or Arroyo La Grieta, this may have been common practice. If so, the purpose would have been to make the metal easier to transport to settlements located farther from the Jándula Valley. In any case, this is very new information that questions the existing idea that all metallurgical processes were carried out within settlements. Future fieldwork will have to focus on defining both the internal structure of these working areas and their role in the structuring and exploitation of these mining territories.

Lead isotope analyses of copper and silver objects show that metal from the eastern Sierra Morena Mountains was distributed throughout the entire south-east of the Iberian Peninsula. We need to continue carrying out isotope analyses and include other areas from the south and centre of the Peninsula to see whether the distribution also extended beyond the Argaric territories. Copper objects originating from the same mineral source are found at different sites located far away from each another. The mines of the central and eastern Sierra Morena Mountains stand out, as they are the most frequent source in the analysed samples, with the Linares-La Carolina mining district being the main producer of copper and silver for the entire south-eastern Peninsula.
Thus, the archaeological record (mines and settlements with metallurgy remains) shows a certain specialisation in metal production in the settlements of those valleys of the eastern Sierra Morena Mountains, although we cannot speak of full-time specialisation on the part of the inhabitants of settlements such as Peñalosa, as metal production did not take place in specific areas, but in dwellings, alongside other productive activities (textile making, food preparation, etc.). These sites would have produced more metal than they needed for their own use, and the surplus would have been traded for finished items and ingots, as shown by the lead isotope analyses. All this justifies considering the Alto Guadalquivir region as an area specialising in copper and silver production within the territory of Argaric culture (Contreras, Cámara 2003; Moreno, Contreras 2010).

Control over metal production and distribution was probably in the hands of elites, and could have been a fundamental factor, although not the only one, in the accentuation of social asymmetry seen in the socalled Alto Guadalquivir Argaric group. The increase in production would not only have been linked to the need for ornamental artefacts and 'arms' as a means of accumulating and displaying wealth and power (plus their use in coercive activities), but also for other items linked to productive activities that until then had been manufactured with other materials.

In conclusion, both the archaeological data and the archaeometric analyses presented in this article show the importance of the Sierra Morena Mountains as the main focal point for copper and silver production in south-eastern Iberia during Late Prehistory, especially in the Argaric Bronze Age. Nonetheless, we must point out that it would not have been the only production centre, although it was clearly the most important. Lead isotope analyses have also determined the existence of other mining areas in the south-east that provided material to various Argaric settlements. These have yet to be identified. Therefore, the hypotheses regarding Argaric metallurgy proposed by the two main lines of interpretation need to be revisited, as the archaeological and analytical data present a much more complex picture than was originally thought. Within this new framework, it seems that large, highly specialised production centres, such as those in the Sierra Morena Mountains, would have coexisted with other mining areas. 


\section{ACKNOWLEDGEMENTS}

This research has been made possible by a contract researcher in the project of the UGR's Own Plan project (2015). Research Projects for the incorporation of young doctors to new lines of research in groups of the UGR (2015) "Minería y metalurgia pre-romana y romana. Explotación y organización de los paisajes mineros del sur de la Peninsula Ibérica (Proyecto MINERO)". It forms part of the following research projects: "La minería romana en Sierra Morena oriental" (2012-2017, DGBC Junta de Andalucía, IP. L. Arboledas) and "Proyecto minería metálica en las Sierras Andaluzas orientales. Desde los orígenes hasta inicios de la Edad Moderna" (HUM7764, IP. F. Conteras).

\section{$\therefore$}

\section{References}

Alarcón E. 2010. Continuidad y cambio social [Recurso electrónico]: las actividades de mantenimiento en el poblado Argárico de Peñalosa (Baños de la Encina, Jaén). Universidad de Granada. Granada.

Ambert P., Figueroa V., Guendon J. L., Klemm V., Laroche M., Rovira S., and Strahm C. 2009. The copper mines of Cabrières (Hérault) in Southern France and the chalcolithic metallurgy. In T. Kienlin, B. Roberts (eds.), Metal and Societies. Studies in honour of Barbara Ottaway. Universitätsforschungen zur Prähistorischen Archäologie 169. Bonn: 285-295.

Aranda Jiménez G., Montón Subías S., and Sánchez Romero, M. 2015. The Archaeology of Bronze Age Iberia: Argaric Societies. Routledge. New York.

Araus J. L., Buxó R., Febrero A., Camalich M. D., Martin D., Molina F., Rodríguez-Ariza M. O., and Voltas J. 1997. Identification of Ancient Irrigation Practise based on the Carbon Isotope Discrimination of Plant Sedds: a Case Study from South-East Iberian Peninsula. Journal of Archaeological Sciencies 24: 729-740.

Arboledas L., Alarcón E., Contreras F., Onorato A., Padilla J. J., and Mora A. 2015. La mina de José Martín PalaciosDoña Eva (Baños de la Encina, Jaén): la primera explotación minera de la Edad del Bronce documentada en el sureste de peninsular. Trabajos de Prehistoria 72 (2): 145162. DOI: $10.3989 /$ tp.2015.12149

Arboledas L., Bashore C., Alarcón E., Contreras F., Moreno A., and Padilla J. J. 2017. Bronze Age mining in southeast Spain. New copper mines from the Jandula and Yeguas Valleys, Sierra Morena. In I. Montero, A. Perea (eds.), Archaeometallurgy in Europe IV. Colección Bibliotheca Praehistorica Hispana 33. Madrid: 49-63.

Arboledas L., Contreras F. 2010. La mina del Polígono o Contraminas (Baños de la Encina, Jaén). Evidencias de la explotación de mineral de cobre en la antigüedad. Cuadernos de Prehistoria y Arqueología de la Universidad de Granada 20: 355-379.
Azcarate J. E. 1972. Los sistemas de fractura filononianas en los Distritos de Linares-La Carolina. Su establecimiento y las reactivaciones posteriores de su capacidad mineralífera. In Actas de las Jornadas Minero-Metalúrgicas IV Nacionales y II Internacionales (Cartagena, 17 a 22 de mayo 1971). Madrid: 553-570.

Bartelheim M., Contreras F., Moreno A., Murillo M., and Pernicka E. 2012. The silver of the South Iberian El Argar Culture: A first look into production and distribution. Trabajos de Prehistoria 69(2): 293-309. DOI: 10.3989/tp.20 12.12093

Blanco A., Rothenberg B. 1981. Exploración arqueometalúrgica de Huelva. Editorial Labor. Barcelona.

Blas-Cortina M. A de 2007-2008. Minería prehistórica del cobre en el reborde septentrional de los Picos de Europa: Las olvidadas labores "El Milagro" (Onís, Asturias). Veleia 24-25: 723-753.

Blas-Cortina M. A. de, Rodríguez F., and Suárez M. 2013. De las labores subterráneas a las actividades metalúrgicas en el exterior: Investigaciones 2007-2012 en las minas de cobre prehistóricas de la Sierra del Aramo ("La Campa les Mines", Concejo de Riosa). Excavaciones arqueológicas en Asturias 2007-2012: 169-187.

Buxó R. 1997. Arqueología de las Plantas. Crítica. Barcelona.

Castaing J., Mille B., Zink A., Bourgarit D., and Ambert, P. 2005. L'abbatage préhistorique au feu dans le district minier de Cabrières (Hérault): évidences par thermoluminiscence (TL). In P. Ambert, J. Vaquer (eds.), La première métallurgie en France et dans les pays limitrophes. Actes du Colloque International. Mémoire XXXVII de la Société Préhistorique Française. Paris: 53-61.

Chapman R. 2008. Producing inequalities: regional sequences in late prehistoric Southern Spain. Journal World Prehistory 21: 195-260. 
Contreras F. 2000. Proyecto Peñalosa. Análisis histórico de las comunidades de la Edad del Bronce del Piedemonte Meridional de Sierra Morena y Depresión Linares-Bailen. Arqueología Monográficas 10. Sevilla.

Contreras F., Cámara J. A. 2002. La jerarquización social en la Edad del Bronce del Alto Guadalquivir (España). El Poblado de Peñalosa (Baños de la Encina, Jaén). British Archaeological Records IS 1025. Archaeopress. Oxford.

Contreras F., Dueñas J., Jaramillo A., Moreno A., Arboledas L., Campos D., García J., and Pérez A. 2005. Prospección arqueometalúrgica en la cuenca alta del río Rumblar. Anuario Arqueológico de Andalucía 2003. II Actividades Sistemáticas: 22-36.

Contreras F., Onorato A., Arboledas L., Alarcón E., Mora A., Fernández J. J., and García A. 2014. Un poblado de la Edad del Bronce que tiene mucho que decir, Peñalosa: últimas novedades. Cuadernos Prehistoria y Arqueología de la Universidad de Granada 24: 111-145.

Delgado S., Escanilla N., and Risch R. 2014. Mazas ocultas. Rastros de minería prehistórica en el Cerro Minado de Huercal-Overa (Almería). Cuadernos Prehistoria y Arqueología de la Universidad de Granada 24: 13-44.

Domergue C. 1987. Catálogo de minas y fundiciones antiguas de la Península Ibérica. Revista Melanges, Casa de Velázquez. Madrid.

Escanilla N., Delgado-Raack S. 2015. Minería prehistórica del cobre (3100-1550 cal ane) en el Levante murciano. In PHICARIA, III Encuentros Internacionales del Mediterráneo. Minería y metalurgia en el Mediterráneo y su periferia oceánica. Universidad Popular de Mazarrón. Mazarrón: 77-99.

Gilman A. 1987. El análisis de clase en la Prehistoria del Sureste. Trabajos de Prehistoria 44: 27-34.

Hanning E., Gaub R., and Goldenberg G. 2010. Metal for Zambujal: experimentally reconstructing a 5000-year-old technology. Trabajos de Prehistoria 67(2): 287-304. DOI: 10.3989/tp.2010.10040

Hernando E. 1907. Los martillos y las piedras con cazoletas de las antiguas minas de cobre de Sierra de Córdoba. Boletín de la Sociedad Española de Historia Natural 6: 279-292.

Hunt M. A. 2003. Prehistoric mining and metallurgy in South-West Iberian Peninsula. British Archaeological Reports IS 1188. Archaeopress. Oxford.

Hunt M., Contreras F., and Arboledas L. 2011. La procedencia de los recursos minerales metálicos en el poblado de la Edad de Bronce de Peñalosa (Baños de la Encina, Jaén). Resultados de análisis de isótopos de plomo. In V Simpo- sio Internacional sobre Minería y Metalurgia Históricas en el Suroeste Europeo, Homenaje a Claude Domergue. SEDPGYM. La Pobla de Segur: 197-208.

Hunt M. A., Llul M., Perelló L., and Salvà B. 2014. Aprovechamiento de recursos cupríferos en la Edad del Bronce de Menorca: la mina de Sa Mitja Lluna (Illa de Colom). Cuadernos de Prehistoria y Arqueología de la Universidad de Granada 24: 45-109.

IGME 1977. Mapa geológico de España, Linares (905 (1936)), E. 1:50.000. IGME. Madrid.

Jaramillo A. 2005. Recursos y materias primas en la Edad del Bronce del Alto Guadalquivir, medioambiente y el registro arqueológico en la cuenca del río Rumblar. Universidad de Granada. Granada.

Lull V. 1983. La cultura del argar. Un modelo para el estudio de las formaciones económico-sociales prehistóricas. Akal. Madrid.

Lull V., Micó R., Risch R., and Rihuete C. 2010. Metal and social relations of production in the $3^{\text {rd }}$ and $2^{\text {rd }}$ millennia BCE in the south-east of the Iberian Peninsula. Trabajos de Prehistoria 67(2): 323-347. DOI: 10.3989/tp.2010.10 042

Mesa y Álvarez P. 1890. Memoria sobre la zona minera Linares-La Carolina. Revista minera, metalurgia y de ingeniería, agosto de 1889 a diciembre de 1890. Madrid.

Montero I. 1991. Estudio Arqueometalúrgico en el sudeste de la Península Ibérica. Universidad Complutense de Madrid. Madrid.

1993. Bronze Age metallurgy in southeast Spain. Antiquity 67: 46-57.

Montero I., Murillo M. 2010. La producción metalúrgica en las sociedades argáricas y sus implicaciones sociales: una propuesta de investigación. Menga 1: 37-51.

Montero I., Rodríguez M. J. 2008. Un pequeño campamento minero de la Edad del Bronce: la Loma de la Tejería (Albarracín, Teruel). Trabajos de Prehistoria 65(1): 155168.

Montes E.-M. 2014. Las prácticas agrícolas en la Alta Andalucía a través de los análisis carpológicos (Desde la Prehistoria Reciente al S. II d.n.e.). Universidad de Jaén. Jaén.

Mora-González A., Fernandes R., Contreras Cortés F., Granados-Torres A., Alarcón-García E., and Delgado-Huertas A. 2018. Reporting atmospheric $\mathrm{CO}_{2}$ pressure corrected results of stable carbon isotope analyses of cereals remains from the archaeological site of Peñalosa (SE Iberian Peninsula): agricultural and social implications. Archaeologi- 
cal and Anthropological Sciences: 1-11. DOI: $10.1007 / \mathrm{s}$ 12520-018-0650-6

Moreno A., Contreras F. 2010. La organización social de la producción metalúrgica en las sociedades argáricas: el poblado de Peñalosa. Menga 1: 53-76.

Moreno A., Contreras F., Renzi M., Rovira S., and Cortés H. 2010. Estudio preliminar de las escorias y escorificaciones del yacimiento metalúrgico de la Edad del Bronce de Peñalosa (Baños de la Encina, Jaén). Trabajos de Prehistoria 67(2): 305-322. DOI: 10.3989/tp.2010.10041

Moreno A., Rovira S., Contreras F., Renzi M., Arboledas L., Alarcón E., Mora A., and García A. 2017: New data on scale production of copper in the culture of the El Argar. The dumping ground for Peñalosa (Baños de la Encina, Jaén). In I. Montero, A. Perea (eds.), Archaeometallurgy in Europe IV. Colección Bibliotheca Praehistorica Hispana 33. Madrid: 65-78.

Murillo M. 2013. Producción y consumo de plata. Un análisis comparativo entre la Sociedad Argárica y los primeros asentamientos orientalizantes del Sur de la Península Ibérica. Universidad de Granada. Granada.

Murillo M., Montero I. 2012. Copper ornaments in the Iberian Chalcolithic: technology versus social demand. Journal Mediterranean Archaeology 25(1): 53-73. http://dx. doi.org/10.1558/jmea.v25i1.53

2014. Producción y distribución de la plata en la sociedad argárica y en los asentamientos orientalizantes. Una aproximación desde el análisis de los isótopos de plomo. In E. García (ed.), II Congreso de Prehistoria de Andalucía, Movilidad, contacto y cambio. Junta de Andalucía, Sevilla: 159-176.

Murillo M., Montero I., and Aranda G. 2015. An insight into the organisation of metal production in the Argaric society. Journal Archaeological Science: Reports 2: 141155. https://doi.org/10.1016/j.jasrep.2015.01.010

O'Brien W. 2004. Ross Island. Mining, Metal and Society in Early Ireland. Bronze Age Studies 6, Departament of Archaeology. National University of Ireland. Galway.
OXALID. http://oxalid.arch.ox.ac.uk/. Consulted: 18-022018.

Pickin J., Timberlake S. 1988. Stone hammers and fire-setting: a preliminary experiment at Cwmystwyth mine, Dyfed. Bulletin of the Peal District Mines Historical Society 10(3): 165-167.

Rodríguez-Ariza M. 2011. Evolución y uso de la vegetación durante la Prehistoria en el Alto Guadalquivir. Menga 2: 37-57.

Rovira S., Gómez Ramos P. 2003. Las Primeras Etapas Metalúrgicas en la Península Ibérica III. Estudios metalográficos. Instituto Universitario Ortega y Gasset. Madrid.

Siret L., Siret H. 1887. Les Premières Âges du Métal dans le Sudest de l'Espagne. Bruxelles.

Stos-Gale Z. H., Hunt M., and Gale N. H. 1999. Análisis elemental de Isótopos de Plomo de objetos metálicos de Gatas. In P. V. Castro, R. Chapman, S. Gili, V. Lull, R. Mico, C. Rihuete, R. Risch, and M. E. Sanahuja (eds.), Proyecto Gatas 2. La dinámica arqueológica de la ocupación prehistórica. Arqueología Monografías, Junta de Andalucía. Sevilla: 347-358.

Stos-Gale S. 2001. The development of Spanish metallurgy and copper circulation in Prehistoric Southern Spain". In B. Gómez, M. A. Respaldiza, and M. L. Pardo (eds.), III Congreso Nacional de Arqueometría. Universidad de Sevilla. Sevilla: 445-456.

Timberlake S. 1990. Excavations and fieldwork on Copa Hill, Cwmystwyth, 1989. In P. Crew, S. Crew (eds.), Early mining in the British Isles. Actas del Workshop Early Mining en Plas Tan y Bwlch. Snowdonia National Park Study Centre: 22-29.

2003. Early mining research in Britain: The development of the last ten years. In P. Craddock, J. Lang (eds.), Mining and Metal Production Through the Ages. The British Museum Press. London: 20-42.

\section{back to contents}

